\title{
Efektifitas Dadih Susu Sapi Mutan Lactococcus lactis terhadap Kanker Pada Mencit yang Diinduksi Benzo[e]piren
}

\author{
Indri Juliyarsi \\ Fakultas Peternakan Universitas Andalas Padang
}

\begin{abstract}
The aims of the present research were to study the effectiveness of fermented buffalo milk (dadih) to control cancer diseases by mice. The research was initiated by preparing dadih fermented with Lactococcus lactis mutant (Dadih SML). The dadih SML product was firstly tested for their toxic potent by using shrimp juvenile (prawn larva of Arthemia Leach Salina) according to method of Brine Shrimp to define the activity of anticarcinogenic potent of dadih. Dadih SML assesses $\mathrm{LC}_{50}$ of $357.7252 \mu \mathrm{g} / \mathrm{ml}$. It means that dadih SML could pursue cancer. Dadih SML was then tested to 18 female mice (Mus musculus) which have been treated with carcinogenic compound of benzo[e]piren. Dadih SML was offered to mice in three doses: $70 \mathrm{mg} / 20 \mathrm{BB}$ g, $126 \mathrm{mg} / 20 \mathrm{BB}$ g and $210 \mathrm{mg} / 20 \mathrm{BB}$. As positive control was used nisin in two doses: $14.4 \mathrm{mg} / 20 \mathrm{BB} g$ and $4.2 \mathrm{mg} / 20 \mathrm{BB}$ $\mathrm{g}$ and negative control was distilled water by $0.4 \mathrm{ml} / 20 \mathrm{BB} \mathrm{g}$. The animals were induced for 10 days by benzo[e Jpiren $0.3 \mathrm{mg} / 20 \mathrm{BB}$ g, and followed for 15 days by tested compound. The results showed that dadih SML with doses of $210 \mathrm{mg} / 20$ BB g could effectively encounter cancer bump volume 72,513\% where heavy change of body and also result of autopsy show normally.
\end{abstract}

Key words: Dadih $S M L, L C_{50}$, benzo[e]piren, nisin, cancer.

\section{Pendahuluan}

Susu fermentasi sudah lama dikenal di Indonesia, khususnya pada daerah Sumatera Barat yang dikenal dengan nama dadih. Dadih merupakan makanan tradisional dari Sumatera Barat yang berasal dari susu kerbau yang dimasukkan ke dalam tabung bambu, ditutup dengan daun pisang dan diperam pada suhu kamar $\pm 30^{\circ} \mathrm{C}$ selama kurang lebih 2 hari sampai susu menggumpal. Dadih sering ditemui pada masyarakat pedesaan yang biasanya digunakan sebagai makanan adat (Sugitha, 1996).

Bakteri asam laktat yang pada umumnya terdapat dalam dadih adalah Lactococcus lactis dan
Lactobacillus achidophillus (Sugitha, 1996). Bakteri ini akan menghasilkan senyawa antibiotika natural yang dapat mengontrol bakteri patogen dalam usus, seperti Lactobacillus achidophillus menghasilkan acidophilin dan Lactococcus lactis menghasilkan nisin (Helferich, 1980). Dari hasil penelitian Hersanti (2001) ditemukan bahwa di dalam dadih susu kerbau yang mengandung bakteri asam laktat, didominasi oleh bakteri Lactooccus yang menghasilkan nisin, yang digunakan sebagai pengawet dalam produk susu dan keju.

Ayebo (1980) dan Sugitha (1996), melaporkan bahwa Lactococcus lactis yang dipakai dalam pembuatan yoghurt (susu fermentasi) 
dan diberikan pada tikus percobaan yang telah disuntik tumor maligna, ternyata sel tumor dapat ditekan hingga $30-45 \%$ karena adanya nisin yang dihasilkan Lactococcus lactis ini dapat mencegah timbulnya kanker.

Penelitian yang dilakukan oleh Gustanti (1999) terhadap uji efek anti kanker dadih sapi yang mengandung bakteri Lactococcus lactis terhadap mencit yang diinduksi benzo[e]piren selama 10 hari dan selanjutnya diberikan dadih susu sapi Lactococcus lactis selama 15 hari, pada beberapa tingkat dosis, yaitu dosis $3,5 \mathrm{~g} / \mathrm{kg} \mathrm{BB}, 6,3 \mathrm{~g} / \mathrm{kg}$ BB dan 10,5 $\mathrm{g} / \mathrm{kg}$ BB sedangkan sebagai pembanding digunakan nisin murni dengan dosis $70 \mathrm{mg} / \mathrm{kg} \mathrm{BB}$ dan 210 $\mathrm{mg} / \mathrm{kg}$ BB. Tingkatan dosis ini diberikan setelah dikonversikan pada kebutuhan dadih untuk manusia per harinya. Hasil dari penelitian ini menunjukkan bahwa dengan pemberian dadih susu sapi yang mengandung bakteri Lactococcus lactis dengan dosis $3,5 \mathrm{~g} / \mathrm{kg} \quad \mathrm{BB}$ menunjukkan pertambahan berat badan 3,53 g dan pengurangan volume benjolan atau kanker sebesar $27,83 \%$ dibandingkan kelompok kontrol yang hanya diinduksi benzo[e]piren tanpa pemberian dadih atau nisin.

Penelitian ini dilakukan dengan tujuan untuk mempelajari efektifitas pemberian dadih yang ditambahkan mutan Lactococcus lactis sebagai starter untuk menanggulangi penyakit kanker pada tikus yang diinduksi dengan benzo[e]piren.

\section{Materi dan Metode}

\section{Tempat dan Waktu}

Penelitian yang dilakukan adalah pembuatan dadih SML, dimana penelitian ini dilaksanakan di Laboratorium Teknologi Hasil Ternak Fakultas Peternakan. Laboratorium Farmakologi, dalam hal uji pendahuluan dengan metode Brine Shrimps dan uji efek dadih SML terhadap kanker pada mencit. Selanjutnya di Laboratorium Biokimia Klinik untuk menguji efek dadih SML terhadap kanker pada mencit dengan pembedahan/autopsi, pada Jurusan Farmasi Fakultas Matematika dan Ilmu Pengetahuan Alam Universitas Andalas yang dilakukan pada bulan Mei sampai dengan Juli 2003.

\section{Alat dan Bahan}

a. Alat - alat

- Seperangkat alat kaca untuk penetas udang, camber, vial, spatel, pinset, pipet dan mikropipet.

- Timbangan analitik, timbangan hewan, alat suntik, alat alat gelas, jangka sorong dan botol.

b. Bahan

Dadih yang mengandung mutan Lactococcus lactis, oleum olivarium, nisin, benzo[e]piren, air suling dan air laut.

c. Hewan Percobaan

- Larva udang Arthemia salina Leach, untuk uji pendahuluan dengan metode Brine Shrimps.

- Mencit putih betina (Mus musculus) galur dyy jepang untuk pengujian efek dadih terhadap perkembangan sel kanker. 


\section{Prosedur kerja}

1. Uji Pendahuluan Toksisitas Dadih Terhadap Larva Udang Arthemia salina Leach

a. Persiapan Alat dan Bahan

Tujuh seri vial yang terdiri atas 3 seri vial untuk dadih SML, 3 seri untuk nisin dan 1 seri untuk kontrol. Satu sari vial terdiri dari 9 vial uji, dimana masing masing vial ditandai dengan konsentrasi 10,100, $1000 \mu \mathrm{g} / \mathrm{ml}$.

b. Persiapan Hewan Percobaan

Hewan percobaan yang dipakai larva udang Arthemia salina Leach. Larva ini diperoleh dengan cara merendam telur udang 2 hari sebelum dilakukan uji. Penetasan dilakukan dengan cara merendam telur tersebut ke dalam air laut secukupnya dan ditempatkan di tempat yang terang.

c. Penyiapan Sampel

Dibuat larutan dadih SML dan nisin dalam air dengan kadar 10 $\mathrm{mg} / \mathrm{ml}$ sebanyak $5 \mathrm{ml}$. Kemudian larutan dadih dan nisin dipipet dan dimasukkan ke dalam vial uji masing - masing sebanyak $5 \mu \mathrm{l}$, $50 \mu \mathrm{l}$ dan $500 \mu \mathrm{l}$ untuk memperoleh kadar akhir $\mu \mathrm{g} / \mathrm{ml}$.

d. Perhitungan $\mathrm{LC}_{50}$

Dilakukan dengan memasukkan larva udang yang baru menetas ke dalam vial uji bersama air laut masing - masing 10 ekor, tepatkan volume dengan air laut hingga $5 \mathrm{ml}$. Simpan di tempat yang cukup cahaya selama 24 jam. Hitung jumlah larva yang mati dan hitung harga $\mathrm{LC}_{50}$ dadih dan nisin dengan komputer program Finney.

2. Uji Efek Dadih SML Terhadap Perkembangan Sel Kanker Pada Mencit

a. Persiapan Hewan Percobaan

Hewan percobaan yang digunakan adalah mencit putih betina (Mus musculus) galur dyy jepang berumur \pm 4 bulan. Hewan ini sebelumnya diadaptasikan selama 15 hari dengan lingkungannya. Selama adaptasi berat badan hewan di timbang, hewan yang digunakan untuk penelitian adalah hewan yang tidak mengalami perubahan berat badan lebih dari $10 \%$ dan perilakunya normal.

b. Penyiapan Sampel

- Penginduksi kanker digunakan larutan benzo[e]piren dalam oleum olivarium dengan dosis $0,3 \mathrm{mg} / 20 \mathrm{~g} \mathrm{BB} /$ hari

- Dadih yang dibuat dari susu sapi dengan penambahan starter mutan Lactococcus lactis

- Larutan nisin dalam air sebagai pembanding.

c. Perlakuan pada Hewan Percobaan

Hewan percobaan dibagi atas 6 kelompok yang masing - masing terdiri dari 3 ekor. Semua kelompok diinduksi dengan benzo[e]piren selama 10 hari secara sub kutan, kemudian dilanjutkan dengan pemberian zat uji selama 15 hari (Sugitha, 1999).

- Kelompok I : Kontrol positif (tidak diberi zat uji) 
- Kelompok II : Diberikan dadih dengan dosis $70 \mathrm{mg} / 20 \mathrm{~g}$ BB

- Kelompok III : Diberikan dadih dengan dosis $126 \mathrm{mg} / 20 \mathrm{~g}$ BB

- Kelompok IV : Diberikan dadih dengan dosis $210 \mathrm{mg} / 20 \mathrm{~g}$ $\mathrm{BB}$

- Kelompok V : Diberikan dadih dengan dosis $1,4 \mathrm{mg} / 20 \mathrm{~g}$ BB

- Kelompok VI : Diberikan dadih dengan dosis 4,2 mg/20 $\mathrm{g}$ BB

d. Pengamatan morfologis benjolan, perubahan berat badan hewan dan kematian/hasil autopsi.

Pengamatan dilakukan dengan menghitung volume benjolan yang terjadi di tubuh mencit. Benjolan yang terbentuk diujur luas dan tingginya. Luas benjolan diukur dengan jangka sorong sedangkan tinggi benjolan ditentukan dengan bantuan penggaris/rol. Kemudian ditentukan volume benjolan dengan memakai rumus kerucut.

Volume benjolan $=1 / 3$ luas benjolan $\mathrm{x}$ tinggi benjolan

Sedangkan perubahan berat badan ditentukan dengan menimbang berat badan mencit selama perlakuan. Untuk kematian ditentukan dengan melihat jumlah kematian sebelum hari akhir perlakuan dan hasil autopsi setelah hari ke -25 .

\section{Evaluasi Data Hasil Penelitian}

Untuk mengevaluasi data hasil penelitian dilakukan dengan uji statistik terhadap varian perlakuan berdasarkan Rancangan Acak Lengkap (RAL) dan uji lanjut dengan metode Duncan New Multiple Range Test (DNMRT).

\section{Hasil dan Pembahasan}

\section{Uji Pendahuluan dengan Metode Brine Shrimp}

Pada uji pendahuluan toksisitas dadih susu sapi mutan Lactococcus Lactis dengan metode Brine Shrimp (Brine Shrimp Letallity Biossay) menggunakan larva udang Athemia salina Leach didapatkan bahwa dadih susu sapi mutan Lactococcus Lactis memiliki aktivitas sitotoksik dengan harga $\mathrm{LC}_{50}$ dibawah 1000 $\mu \mathrm{g} / \mathrm{ml}$, yaitu $357,7252 \mu \mathrm{g} / \mathrm{ml}$ dan dibandingkan dengan penelitian sebelumnya yang menggunakan wild type dari Lactococcus lactis, kemampuannya sebesar 402,8161 $\mu \mathrm{g} / \mathrm{ml}$ (Gustanti, 1999). Dibawah ini terdapat hasil uji pendahuluan toksisitas dengan metode Brine Shrimp.

Penelitian yang diawali dengan uji pendahuluan sitotoksisitas dadih susu sapi mutan Lactocococcus lactis dengan metode Brine Shrimp (The Brine Shrimp Letallity Biossay), yang merupakan penapisan awal yang dapat dilakukan pada ekstrak atau senyawa murni untuk melihat aktivitas sitotoksiknya, yang diduga mempunyai efek sebagai anti kanker.

Penentuan tingkat toksisitas dadih SML dan nisin terhadap larva udang dapat dilakukan dengan menghitung harga $\mathrm{LC}_{50}$ nya, dalam hal ini dengan menggunakan komputer Finney, dimana bila harga $\mathrm{LC}_{50}$ lebih kcil dari $1000 \mu \mathrm{g} / \mathrm{ml}$ maka dianggap aktif dan sebaliknya harga LC $_{50}$ lebih besar dari 1000 $\mu \mathrm{g} / \mathrm{ml}$ berarti tidak aktif sitoksisnya. Standar nilai ini diambil sesuai dengan yang ditetapkan Meyer. 
Berdasarkan hasil uji pendahuluan dengan menggunakan larva udang didapatkan bahwa dadih SML bersifat aktif sitoksisnya dengan harga $\mathrm{LC}_{50} 357,7252 \mu \mathrm{g} / \mathrm{ml}$ dan nisin sebagai pembanding mempunyai $\mathrm{LC}_{50} \quad 201,1801 \mu \mathrm{g} / \mathrm{ml}$, sehingga dapat diuji lanjut. Senyawa yang bersifat aktif sitotoksik biasanya dapat menekan dan menghancurkan perkembangan sel kanker, namun juga dapat menghambat pembelahan sel normal yang proliferasinya cepat seperti sumsum tulang, mukosa saluran cerna, folikel rambut dan jaringan limfosit. Suatu senyawa dikatakan mempunyai terapi kanker yang baik bila dalam dosis yang digunakan dapat mematikan sel tumor dan tidak terlalu menganggu sel normal yang berproliferasi (Anderson, 1991 cit Gustanti,1999).

\section{Uji Efek Dadih SML Terhadap} Perkembangan Sel Kanker Pada Mencit

\section{Volume Benjolan}

Pada pengujian efek anti kanker dadih susu sapi mutan Lactococcus lactis yang dilakukan pada mencit yang telah diinduksi benzo[e]piren didapatkan hasil sebagaimana tercantum pada Tabel 2. Pengujian dilakukan untuk melihat efektivitas dadih SML terhadap mencit putih betina (Mus musculus) galur dyy jepang yang sebelumnya diinduksi kanker dengan benzo[e]piren selama 10 hari secara sub kutan dengan volume pemberian $0,1 \mathrm{ml} / 20 \mathrm{~g} \mathrm{BB}$ mencit. Kemudian selama 15 hari berikutnya mencit diberikan dadih SML dengan dosis $70 \mathrm{mg} / 20 \mathrm{~g} \mathrm{BB}$, $126 \mathrm{mg} / 20 \mathrm{~g}$ BB dan $210 \mathrm{mg} / 20 \mathrm{~g}$ BB. Nisin yang digunakan sebagai pembanding diberikan dengan dosis $1,4 \mathrm{mg} / 20 \mathrm{~g}$ BB dan $4,2 \mathrm{mg} / 20 \mathrm{~g} \mathrm{BB}$. Tingkatan dosis ini diberikan setelah dikonversikan pada kebutuhan dadih untuk manusia yang menderita kanker perharinya. Sebagai kontrol positif digunakan mencit yang diinduksi kanker dan selama 15 hari berikutnya diberi aquadest 0,4 $\mathrm{ml} / 20 \mathrm{~g}$ BB. Benzo[e]piren diberikan selama 10 hari karena sel kanker akan tumbuh setelah terinduksi antara $9-13$ hari. Pada periode ini terlihat dan terasa perubahan pada tengkuk dan kaki mencit. Benjolan terus tumbuh membesar dan benjolan tersebut bersifat keras.

Tabel 1. Hasil Uji Pendahuluan Toksisitas Dadih SML dan Nisin

\begin{tabular}{|l|c|c|c|c|c|c|c|}
\hline \multirow{2}{*}{\multicolumn{1}{c|}{ Parameter }} & \multirow{2}{*}{ Kontrol } & \multicolumn{3}{c|}{$\begin{array}{c}\text { Kosentrasi Dadih SML } \\
(\mu \mathrm{g} / \mathrm{ml})\end{array}$} & \multicolumn{3}{c|}{$\begin{array}{c}\text { Konsentrasi Nisin } \\
(\mu \mathrm{g} / \mathrm{ml})\end{array}$} \\
\cline { 3 - 9 } & & 10 & 100 & 1000 & 10 & 100 & 1000 \\
\hline Jumlah Kematian (ekor) & 0 & 3 & 6 & 75 & 9 & 12 & 84 \\
\hline Total Sampel (ekor) & 90 & 90 & 90 & 90 & 90 & 90 & 90 \\
\hline \% Kematian & 0 & 3,33 & 6,67 & 83,33 & 10 & 13,33 & 93,33 \\
\hline Log Konsentrasi & & 1,0 & 2,0 & 3,0 & 1,0 & 2,0 & 3,0 \\
\hline Nilai Probit & & 2,298 & 4,037 & 5,776 & 3,116 & 4,561 & 6,006 \\
\hline LC $_{50}$ & & \multicolumn{3}{|c|}{$357,7252 \mu \mathrm{g} / \mathrm{ml}$} & \multicolumn{5}{c|}{$201,1801 \mu \mathrm{gg} / \mathrm{ml}$} \\
\hline
\end{tabular}

Keterangan: * Perhitungan dilakukan dengan komputer Finney 
Tabel 2. Volume Benjolan Setelah Pemberian Dadih SML dan Nisin

\begin{tabular}{|l|c|c|c|c|c|c|}
\hline \multirow{2}{*}{\multicolumn{1}{|c|}{ Perlakuan }} & \multicolumn{4}{|c|}{ Volume Benjolan $\left(\mathrm{cm}^{3}\right)$} & \multirow{2}{*}{ Total } & $\begin{array}{c}\text { Rata- } \\
\text { rata }\end{array}$ \\
\cline { 2 - 6 } & 1 & 2 & 3 & $\begin{array}{c}\text { Pengurangan } \\
\text { Terhadap } \\
\text { Kontrol }\end{array}$ \\
\hline Kontrol & 1,742 & 1,636 & 1,337 & 4,715 & 1,572 & 0 \\
\hline $\begin{array}{l}\text { Dadih dosis } \\
70 \mathrm{mg} / 20 \mathrm{~g} \text { BB }\end{array}$ & 1,058 & 1,066 & 1,074 & 3,198 & 1,066 & 32,174 \\
\hline $\begin{array}{l}\text { Dadih dosis } \\
126 \mathrm{mg} / 20 \mathrm{~g} \text { BB }\end{array}$ & 1,019 & 1,034 & 1,029 & 3,082 & 1,027 & 34,634 \\
\hline $\begin{array}{l}\text { Dadih dosis } \\
210 \mathrm{mg} / 20 \mathrm{~g} \text { BB }\end{array}$ & 0,440 & 0,490 & 0,366 & 1,296 & 0,432 & 72,513 \\
\hline $\begin{array}{l}\text { Nisin dosis } \\
1,4 \mathrm{mg} / 20 \mathrm{~g} \text { BB }\end{array}$ & 0,351 & 0,354 & 0,470 & 1,175 & 0,392 & 75,080 \\
\hline $\begin{array}{l}\text { Nisin dosis } \\
4,2 \mathrm{mg} / 20 \mathrm{~g} \mathrm{BB}\end{array}$ & 0,460 & 0,660 & 0,620 & 1,740 & 0,580 & 63,097 \\
\hline
\end{tabular}

Pemberian dadih SML dan nisin pada hari ke 11 sampai ke 25 dapat menghambat pertumbuhan sel kanker, dibawah ini terdapat gambar kelompok perlakuan dadih SML dosis $210 \mathrm{mg} / 20 \mathrm{~g}$ BB yang dapat menekan pertumbuhan kanker sampai $72,513 \%$ dan kelompok nisin dosis $1,4 \mathrm{mg} / 20 \mathrm{~g}$ BB yang dapat menghambat pertumbuhan kanker sebesar 75,080 \%. Berdasarkan nilai statistika menunjukan bahwa kelompok dadih SML dosis $210 \mathrm{mg} / 20 \mathrm{~g} \mathrm{BB}$ dan nisin $1,4 \mathrm{mg} / 20$ g BB memiliki khasiat yang sama dalam menekan pertumbuhan kanker, ini berarti nisin murni dapat disubstitusi oleh dadih SML, dimana harganya lebih murah dan mudah didapat dibandingkan dengan nisin yang harus diimpor dari luar negeri.

Bakteri Lactococcus lactis ini akan memfermentasikan laktosa menjadi asam laktat dan menghasilkan produk antibiotika nisin. Nisin yang dihasilkan dari susu fermentasi (yoghurt) dan diberikan pada tikus percobaan yang telah disuntik dengan sel tomor maligna, ternyata sel tumor dapat ditekan hingga $30-45 \%$ (Ayebo, 1980). Demikian juga penelitian yang dilakukan Gustanti (1990) dengan menggunakan dadih susu sapi yang diberi bakteri Lactococcus lactis asli (wild type). Perlakuan ini diuji cobakan kepada mencit yang telah diinduksi benzo[e]piren dan diperoleh hasil bahwa pertumbuhan kanker dapat ditekan hingga 27,83 $\%$.

Penentuan aktivitas anti kanker dilakukan dengan pengamatan terhadap benjolan yang tumbuh dan pengamatan perubahan berat badan serta hasil autopsi setelah 25 hari perlakuan. Pada pengamatan bentuk morfologis mencit, terlihat kelompok kontrol mempunyai benjolan paling besar dibandingkan dengan kelompok lain dengan volume sebesar $1,572 \mathrm{~cm}^{2}$. Hal ini disebabkan karena kelompok kontrol tidak diberikan senyawa uji yang dapat menghambat volume benjolannya, dimana senyawa uji yaitu dadih SML mengandung nisin yang berfungsi menghambat pertumbuhan dan perkembangan kanker. 
Pada tiga kelompok pemberian dadih SML, volume terkecil terlihat pada kelompok dadih SML dosis 210 $\mathrm{mg} / 20 \mathrm{~g}$ BB dengan pengurangan volume benjolan terhadap kontrol $72,513 \%$ dibandingkan dengan kontrol. Pada dadih SML $126 \mathrm{mg} / 20$ g BB, volume benjolan $1,027 \mathrm{~cm}^{3}$ dengan pengurangan volume 34,634 $\%$ terhadap kontrol dan dadih SML dosis $70 \mathrm{mg} / 20 \mathrm{~g} \mathrm{BB}$, pengurangan volume benjolan terhadap kontrol sebesar $32,174 \%$.

Dari data ini diketahui dosis yang efektif untuk pemberian dadih SML adalah $210 \mathrm{mg} / 20 \mathrm{~g} \mathrm{BB}$, dilihat dari kemampuannya menekan perkembangan sel kanker, hal ini disebabkan karena dalam dosis ini dadih SML mengandung antibiotika nisin dalam jumlah yang sesuai untuk menahan pertumbuhan kanker yang disebabkan oleh benzo[e]piren. Jika dikonversikan pada kebutuhan manusia berdasarkan tabel konversi dosis dadih SML $210 \mathrm{mg} / 20 \mathrm{~g}$ BB mencit setara dengan dosis $81,459 \mathrm{~g}$ untuk manusia penderita kanker yang mempuyai berat badan $70 \mathrm{~kg}$.

Dadih yang mengandung mutan Lactococcus lactis ini mampu menghambat kanker yang disebabkan oleh benzo[e]piren karena adanya nisin yang terkandung didalamnya (Ayebo, 1980). Pengujian statistika dengan analisis varian dan dilanjutkan dengan uji DNMRT $5 \%$ dan $1 \% \quad(\mathrm{p}<0,05$ dan 0,01$)$ didapatkan bahwa dadih SML dosis $210 \mathrm{mg} / 20 \mathrm{~g}$ BB dan nisin dosis 1,4 $\mathrm{mg} / 20 \mathrm{~g} \mathrm{BB}$ serta nisin dosis 4,2 mg mempunyai nilai signifikan dan memiliki kemampuan yang sama dalam menahan pertumbuhan benjolan kanker jika dibandingkan dengan kelompok dadih SML dosis $70 \mathrm{mg} / 20 \mathrm{~g} \mathrm{BB}$ dan dadih SML dosis $126 \mathrm{mg} / 20 \mathrm{~g}$ BB serta kelompok kontrol, hasil pengujiannya sangat berbeda nyata.

Berat Badan

Pengamatan selanjutnya adalah perubahan berat badan selama perlakuan dengan membandingkan berat badan hewan pada hari ke -1 dengan hari ke -25 , dapat dilihat pada Tabel 3.

Pertambahan berat badan yang paling besar pada dosis $210 \mathrm{mg} / 20 \mathrm{~g}$ BB ini disebabkan karena dadih SML dengan dosis tersebut mengandung komposisi gizi yang sesuai dengan pertumbuhan mencit dan nisin yang terkandung di dalamnya mampu menghambat pertumbuhan sel kanker dengan efektif.

\section{Kematian dan Hasil Autopsi}

Pada kelompok kontrol yang tidak diberi senyawa uji (pemberian aquadest $0,4 \mathrm{ml} / 20 \mathrm{~g} \mathrm{BB}$ ) dari hasil autopsi didapatkan data pada bagian organ dalam seperti hati, jantung, paru - paru, usus mengalami pembusukan (hitam) dan tulang kaki rapuh serta memutih sedangkan pada tengkuk bagian dalam mengalami kerusakan pada jaringan otaknya. Mencit yang mati sebelum hari akhir perlakuan berjumlah dua ekor dari lima ekor atau $40 \%$ dari kematian pada hari ke - 12 dan 14. Ini disebabkan karena benzo[e]piren telah bekerja menyerang organ dalam dan luar mencit.

Kelompok pemberian dadih SML dengan dosis $70 \mathrm{mg} / 20 \mathrm{~g} \quad \mathrm{BB}$, didapatkan hasil autopsi dari mencit yang mati adalah organ dalam seperti hati, jantung, dan usus mengalami pembusukan sebagian sedangkan paru - paru normal dan tulang kaki kiri rapuh memutih. Mencit yang 
mati sebelum hari akhir perlakuan berjumlah dua ekor dari lima ekor atau $40 \%$ dari kematian pada hari ke - 14 dan 15. Ini disebabkan karena benzo[e]piren telah bekerja menyerang organ dalam dan luar mencit, dadih SML dosis $70 \mathrm{mg} / 20 \mathrm{~g}$ BB ternyata kandungan nisisnnya tidak efektif dalam menghambat pertumbuhan kanker.

Untuk dadih SML dosis $\mathrm{mg} / 20 \mathrm{~g}$ $\mathrm{BB}$, hasil autopsi dari mencit yang mati adalah organ dalam seperti hati, jantung, limpa dan usus mengalami pembusukan sebagian kecil sedangkan paru - paru normal dan tulang kaki kiri rapuh memutih. Kematian pada mencit hanya satu ekor $(20 \%)$ diahri ke 18, ini berarti kandungan nisin sudah mampu menghambat pertumbuhan kanker.

Dadih SML dosis $210 \mathrm{mg} / 20 \mathrm{~g}$ $\mathrm{BB}$, hasil yang diperoleh adalah untuk dosis ini tidak terjadi kematian sebelum hari ke -25 , jadi semua mencit hidup. Hal ini menunjukkan bahwa dosis ini mempunyai kandungan nisin yang tepat untuk menghambat kanker. Hasil autopsi setelah hari ke - 25 adalah pada organ dalam seperti hati, jantung, usus dan paru - paru normal, demikian juga bagian yang bengkak pada kaki tidak merusak tulang bagian dalam dan pembengkakan diluar setelah dibedah mengeluarkan cairan bening kental.

Hasil autopsi dari masing masing kelompok dapat dilihat bahwa mencit pada kelompok kontrol, setelah dilakukan pembedahan pada bagian tengkuknya didapatkan bahwa bagian dalamnya hancur dan mengeluarkan cairan berwarna putih sehingga jaringan otaknya juga hancur. Jika dibandingkan dengan kelompok dadih SML dosis $210 \mathrm{mg} / 20 \mathrm{~g} \mathrm{BB}$, dimana pada dosis ini jaringan otak dan bagian dalamya normal.

Tabel 3. Rata - rata Berat Badan dan Besar Perubahan Berat Badan pada Mencit Selama 25 Hari Perlakuan dengan Dadih SML dan Nisin (gram)

\begin{tabular}{|c|c|c|c|c|c|c|c|c|}
\hline \multirow{2}{*}{ Kelompok } & \multicolumn{7}{|c|}{ Berat Badan (g) } \\
\cline { 2 - 9 } & $\begin{array}{c}\text { Hari } \\
\text { ke-1 }\end{array}$ & $\%$ & $\begin{array}{c}\text { Hari } \\
\text { ke-11 }\end{array}$ & $\%$ & $\begin{array}{c}\text { Hari } \\
\text { ke-21 }\end{array}$ & $\%$ & $\begin{array}{c}\text { Hari } \\
\text { ke-25 }\end{array}$ & $\%$ \\
\hline I & 33,17 & 0 & 38,17 & 15,07 & 35,00 & 5,51 & 34,50 & 4,00 \\
\hline II & 31,17 & 0 & 33,17 & 6,42 & 32,33 & 3,57 & 31,67 & 1,60 \\
\hline III & 30,67 & 0 & 36,00 & 17,38 & 32,00 & 4,34 & 30,67 & 0 \\
\hline IV & 29,33 & 0 & 33,67 & 14,80 & 33,17 & 13,06 & 32,33 & 10,23 \\
\hline V & 29,67 & 0 & 35,50 & 19,65 & 31,00 & 4,48 & 31,83 & 7,31 \\
\hline VI & 28,50 & 0 & 32,67 & 14,63 & 27,83 & $-2,35$ & 28,33 & $-0,60$ \\
\hline
\end{tabular}

$\begin{array}{lll}\text { Keterangan : } & \text { I } & \text { : Kelompok kontrol } \\ & \text { II } & : \text { Kelompok yang diberi dadih SML dosis } 70 \mathrm{mg} / 20 \mathrm{~g} \mathrm{BB} \\ & \text { III } & : \text { Kelompok yang diberi dadih SML dosis } 126 \mathrm{mg} / 20 \mathrm{~g} \mathrm{BB} \\ & \text { IV } & : \text { Kelompok yang diberi dadih SML dosis } 210 \mathrm{mg} / 20 \mathrm{~g} \mathrm{BB} \\ \text { V } & : \text { Kelompok yang diberi dadih nisin dosis } 1,4 \mathrm{mg} / 20 \mathrm{~g} \mathrm{BB} \\ & \text { VI } & : \text { Kelompok yang diberi dadih nisin dosis } 4,2 \mathrm{mg} / 20 \mathrm{~g} \mathrm{BB}\end{array}$


Untuk kelompok nisin dosis 1,4 $\mathrm{mg} / 20 \mathrm{~g} \mathrm{BB}$, menit yang digunakan tetap hidup sampai perlakuan berakhir, berarti efek dadih SML dosis $210 \mathrm{mg} / 20 \mathrm{~g}$ BB mampunyai kandungan nisin yang hampir sama dengan nisin 1,4 mg/20 g BB. Berarti nisin murni yang digunakan dapat disubstitusi oleh dadih SML dosis $210 \mathrm{mg} / 20 \mathrm{~g} \mathrm{BB}$, walaupun secara ilmiah kandungan nisin dalam dadih belum bisa dihitung, namun telah dipastikan bahwa dalam dadih pada penelitian ini mengandung mutan Lactococcus lactis yang menghasilkan nisin. Secara umum dadih SML dosis $210 \mathrm{mg} / 20 \mathrm{~g}$ BB ini mempunyai khasiat yang hampir sama dengan nisin murni. Dari pembedahan terhadap hewan yang telah dimatikan, hasil autopsinya organ dalam seperti hati, jantung, paru - paru normal, demikian juga bagian yang bengkak pada kaki tidak merusak tulang bagian dalam dan pembengkakkan diluar setelah dibedah mengeluarkan cairan bening kental.

Kelompok nisin dosis 4,2 mg/20 g BB, mencit yang diberi perlakuan mengalami kematian sebelum akhir perlakuan berjumlah satu ekor (20 $\%$ ) yang mati pada hari ke -23 . ini disebabkan karena terlalu tingginya kandungan nisin dan tingkat keasaman yang tinggi menyebabkan gangguan pencernaan sehingga pada kelompok ini terjadi penurunan berat badan yang drastis dibandingkan dengan kelompok lain.

Pembedahan juga dilakukan pada mencit yang mengalami pembengkakan di kaki, hasilnya diperoleh bahwa pada bagian dalam (jaringan tulang) terjadi perapuhan dan dilihat organ dalam pada umumnya kanker tidak menyerang paru - paru, bagian yang menghitam pada organ dalam itu disebabkan terjadinya pembekuan darah yang berlebihan. Benzo[e]piren yang digunakan sebagai stimulan kanker ini adalah kelompok senyawa yang bekerja sebagai karsinogen yaitu hidrokarbon aromatik polisiklik. kemampuan benzo[e]piren ini dalam menyerang anggota tubuh dari mencit ini cukup tinggi, sehingga menyebabkan mencit yang digunakan mati sebelum hari akhir perlakuan.

Dari hasil pembedahan terhadap dua ekor mencit pada kelompok kontrol dapat dilihat pada mencit yang mati hari ke -12 , tulang kaki dalamnya rapuh sedangkan organ dalam normal. Mencit yang mati hari ke -14 , terjadi pembusukan sebagian organ dalam, sedangkan usus dan ginjal masih normal. Hal ini disebabkan pada periode tersebut, benzo[e]piren telah mulai bekerja aktif menyerang semua organ dalam dan luar dari mencit, juga diamati perilaku dari kelompok kontrol yang cenderung pasif dalam bergerak. Sedangkan pada kelompok dadih SML dosis $210 \mathrm{mg} / 20 \mathrm{~g} \mathrm{BB}$, bagian organ dalam masih normal, autopsi ini dilakukan setelah 25 hari perlakuan.

\section{Kesimpulan}

Dadih susu sapi mutan Lactococcus lactis mempunyai efek anti kanker berdasarkan uji sitotoksitasnya dengan metode Brine Shrimp dengan harga $\mathrm{LC}_{50} 357,7252$ $\mu \mathrm{g} / \mathrm{ml}\left(\mathrm{LC}_{50}<1000 \mu \mathrm{g} / \mathrm{ml}\right)$. Hasil ini lebih baik bila dibandingkan dengan dadih susu sapi Lactococcus lactis (wild type) mempunyai harga LC 50 $402,8161 \mu \mathrm{g} / \mathrm{ml}$. Pemberian dadih susu sapi mutan Lactococcus lactis 
dengan dosis $70 \mathrm{mg} / 20 \mathrm{~g} \mathrm{BB}, 126$ $\mathrm{mg} / 20 \mathrm{~g} \mathrm{BB}$ dan $210 \mathrm{mg} / 20 \mathrm{~g} \mathrm{BB}$ dapat menghambat perkembangan sel kanker pada mencit yang diinduksi dengan benzo[e]piren secara berarti $(\mathrm{p}<0,05$ dan 0,01$)$, dengan penghambatan benjolan kanker pada tubuh mencit yang efektif adalah dadih SML dosis 210 $\mathrm{mg} / 20 \mathrm{~g}$ BB dengan pengurangan pada volume benjolan mencapai $72,513 \%$.

\section{Daftar Pustaka}

Ayebo, A.D. 1980. Effectivities Fermented Milk to Decreasing Cancer and Tumor Attack. Nebraska University. New Delhi.

Eckner, K.F. 1991. Bacteriocin and Food Application. Scope. Volume VI September.

Einarson, H., H. Lauzon. 1994. Biopreservative of Brine Shrimp by Bacteriocins From Lactic Acid Bacteria. J. Appl and Enviroment. Microbiol. 669 676.

Fardiaz, S. 1988. Fisiologi Fermentasi. Pusat Antar Universitas. IPB. Bogor.

Ferber, D. 2001. Food Prewservative or Powerful Antibiotic? Nisin Z Could Both. Article Lycos Health.

Frank, C. L, . Toksologi Dasar, Azas, Organ Sasaran dan Penilaian Resiko. Terjemahan E. Nugroho. Edisi Kelima. UI Pres. Jakarta.

Friedman, Y. 1996. Lactid Acid Bacteria As Foos Preservative. Int J. Food Microbiol.
Gustanti, E. 1999. Uji Efek Anti Kanker Dadih S. lactis terhadap Mencit yang Diinduksi dengan Benzo[e]piren. Skripsi Sarjana. Fakultas Matematika dan Ilmu Pengetahuan Alam. Universitas Andalas. Padang.

Harsanti, S.U. 2001. Uji Bioaktivitas Bakteriosin pada Dadih di Sumatera Barat. Tesis Pasca Sarjana. Universitas Andalas. Padang.

Helfrerich, W and D. Westhoff. 1980. All About Yoghurt. Prentice Hall, Inc. Englewood Cliffs. New Jersey.

Meyer, B.N., N.R. Ferrigni, J. E. Putman, L.B. Jacobsen, D.E. Nichols and J.L. Mc Laughlin, 19. Brine Shrimp : A Convenient General Biossay for Active Plant Constituent. In Planta Med 45.

Mulyani. 2001. Skrining Mutan dan Uji Aktivitas Bakteriosin dari Bakteri Asam Laktat. Tesis Pascasarjana. Universitas Andalas. Padang.

Sugitha, I.M dan M. Djalil.1989. Susu, Penanganan dan Teknologinya. Fakultas Peternakan. Universitas Andalas. Padang.

Hindari Serangan Tumor dan Jantung. Singgalang 4 September 1994.

. 1995. Olahan Susu Kerbau Tradisional Minang, Manfaat, Kendala, dan Prospeknya dalam Era Industrialisasi Sumatera Barat. Seminar Sehari teknologi Hasil ternak. Fakultas 
Peternakan. Universitas Andalas. Padang.

H, Muchtar, Kharsad

dan Yuherman. 1999. Rekayasa

Dadih dengan Streptococcus

lactis dan Lactobacillus achido- phillus untuk Mencegah dan Mengurangi Kolesterol Darah. Laporan Hibah Bersaing Perguruan Tinggi. Fakultas Paternakan Universitas Andalas. Padang.

Alamat korespondensi: Indri Juliyarsi

Jurusan Produksi Ternak Fakultas Peternakan

Universitas Andalas, Kampus Limau Manis Padang.

Telp/Fax: 0752-71464, HP: 08126744736

Artikel diterima: 25 Juni 2004, disetujui: 31 Desember 2004 